\title{
Knowledge and attitude about risky pregnancy among student
}

\author{
Suci Musvita Ayu, S. Lindawati, Thoharoh Halimatusa'diyah \\ Department of Public Health, Universitas Ahmad Dahlan, Indonesia
}

\section{Article Info}

Article history:

Received Dec 2, 2019

Revised Feb 14, 2020

Accepted May 5, 2020

\section{Keywords:}

Adolescents

Behavior

Counseling

Risky pregnancy

Student

\begin{abstract}
This study was conducted examine the effect of counseling on the increasing knowledge and attitudes about risky pregnancies at Muhammadiyah 1 Vocational High School in Wonosobo, Indonesia. This research was quasi-experimental research employed quasi experiment design with one group pretest-post-test design. Measurements were made before and after treatment, by doing a pre-test and post-test. Sample sie in this study was 108 students. The instrument in this study is the questionnaire. The results of the knowledge variable showed a significant value 0.003 . There is an effect of reproductive health counseling on increasing knowledge and attitudes about risky.
\end{abstract}

This is an open access article under the CC BY-SA license.

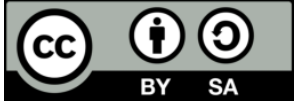

\section{Corresponding Author:}

Suci Musvita Ayu, Department of Public Health, Universitas Ahmad Dahlan, Jl. Prof. Dr. Soepomo, Janturan, Yogyakarta (55164), Indonesia.

Email: suci.ayu@ikm.uad.ac.id

\section{INTRODUCTION}

The case of sexual behavior in adolescents is increasingly worrisome because teenage sexual behavior is now exceeding the limits and quite alarming [1]. This is supported by research showing $12.1 \%$ of adolescents have sexual behavior at risk of unwanted pregnancy. An unwanted pregnancy in adolescence is caused by several factors, one of which is the educational prospect, some of which do not know how to avoid pregnancy [2]. Early childbirth is a major health risk for mothers, in low and middle income countries, complications of pregnancy and childbirth are the main causes of death in young women aged 15-19 years [3].

Indonesia's 2012 Demographic Health Survey, 1.6\% of women and 21\% of men between the ages of 15 and 19 are estimated to have sexual relations before the age of 15 years. Adolescents have inadequate access to appropriate sexual and reproductive health information [4]. Adolescent girls and boys in Indonesia who know about fertility only reach $29.0 \%$ and $32.3 \%$. Adolescents who know the risk of pregnancy if they have sexual intercourse once, only reach $49.5 \%$ and $45.5 \%$, respectively. Male and female adolescent aged 14-19 years who claimed to have friends who had had premarital sexual relations reached $48.6 \%$ and $46.5 \%$ respectively [5].

The development of the current era, also influence sexual behavior in dating teenagers. For example, it can be seen that things tabooed by teenagers in the past few years, such as kissing and making out, have now been justified by teenagers now. There is even a small portion of them agree with free sex. This condition is quite alarming considering that this behavior can lead to Unwanted Pregnancy Cases (KTD) which further trigger unsafe abortion practices, transmission of STDs and HIV/AIDS, even death [6]. Teenagers want to try anything that is done by adults, including sexuality because they want to be considered 
old enough. During the transition period adolescents have complex and complex problems. This condition can change adolescent sexual views so that they deviate from the norms in society, so that they are vulnerable to falling into drug abuse, physical violence, smoking, immoral acts, reproductive problems, STDs (Sexually Transmitted Diseases) due to free sex such as HIV/AIDS [7]. Free sex performed by adolescents has a high risk of causing pregnancy. A teenager who gets pregnant before marriage occurs causes her to be unprepared and unwilling to face her pregnancy. Unwanted Pregnancy (KTD) is a pregnancy that due to various things its existence is undesirable by one of the two candidate's even fetal parents [8]. According to 2017 IDHS data the number of unwanted pregnancies is $12 \%$ and $7 \%$ of men report their partners having unwanted pregnancies. Unwanted pregnancies in the 15-19 year age group are twice as large (16\%) than the 20-24 year age group (8\%) [9]. Increased sexual interest and lack of knowledge of adolescents about premarital sexual behavior, coupled with a lack of family openness in discussing sexual problems is one of the factors teenagers fall into the form of premarital sexual behavior [10].

Knowledge is one of the predisposing factors for a risky pregnancy. Less of knowledge or limited knowledge about high-risk pregnancies and the dangers that will be experienced, will also increase the incidence of high-risk pregnancy, behavioral and socioeconomic also affect the risks in pregnancy $[11,12]$. Knowledge and practice at the adolescent stage will be the basis of healthy behavior at a later stage in life. Thus, investing in adolescent reproductive health programs during life will be beneficial [13]. According to the 2012 IDHS KRR shows the level of knowledge of adolescents about reproductive health is still low with the results of $73.46 \%$ of adolescent boys and $75.6 \%$ of adolescent girls aged 15-19 years in Indonesia do not know enough knowledge about reproductive health [14]. Many problems will arise due to ignoring reproductive health. Problems arising from lack of knowledge of reproductive health are unwanted pregnancy, abortion, early marriage and marriage, STIs or STDs and HIV/AIDS [15]. Basic knowledge that needs to be given to adolescents includes the introduction of reproductive systems, processes and functions (aspects of adolescent growth and development) and also why adolescents need to mature their marriage age and how to plan a pregnancy to suit their desires and partners to avoid risky pregnancies. The process of reproduction is the process of continuing offspring which is the joint responsibility of both men and women. Therefore both young men and women must know and understand about various aspects of reproductive health including avoiding risky pregnancies [16].

The current era of communication and information globalization, adolescents can easily access information from various parts of the world with diverse cultural patterns, so that opportunities for adolescents to be contaminated with information are often even contradictory or even contrary to the culture of their own communities. In this condition, without adequate guidance and assistance, adolescents will be easily affected by misleading information and carried by unhealthy social interactions, given that adolescents do not yet have a filter strong enough to filter the various information they receive, nor do they have the deterrent power to ward off the dominance of the social environment, due to adolescent personality is still unstable and the level of knowledge is still minimal [17]. In addition to knowledge, adolescent attitudes towards pregnancy at an early age are an important part of being able to understand the phenomenon of an increasing number of cases of early pregnancy which are very risky. Attitude is a willingness or readiness to behave [18]. Social attitudes and norms are an important part of adolescent life in making decisions to behave risky. Research conducted by Dewi shows that adolescents have good knowledge but do not consistently show good attitudes towards pregnancy in their teens. Adolescents have negative attitudes that lead to high risks such as hugging during courtship and kissing forehead [19].

Primary health care with the Adolescent Health Care Services (AHCS) provide health services for school-based and community-based youth. AHCS in primary health care is adjusted to the needs of adolescents by increasing the quality of counseling of health personel and empowering adolescents as peer counselors. Peer counselors are an event to complain to each other, pour out their hearts, strengthen each other and motivate each other among fellow students [20]. Basic counseling skills training must be carried out for Information and Health Counseling Center Teenage Reproduction (IHC-CTR) administrators at Muhammadiyah 1 Vocational High School in Wonosobo on a module-based basis through reading activities, discussion activities, and practicing activities so that Youth Information and Counseling Center (YIAC) administrators can have knowledge and insight about the implementation of counseling as an effort to solve problems and can help the implementation of the duties of counseling guidanceteachers in peer service relations. However, in The Muhammadiyah 1 Vocational High School in Wonosobo there has not been a training in counseling skills for students even though in Muhammadiyah 1 Vocational High School in Wonosobo already has a IHC-CTR program. Therefore the IHC-CTR program at Muhammadiyah 1 Vocational High School in Wonosobo did not run well.

Adolescents aged 15-19 years are vulnerable to reproductive problems, one of which is the occurrence of risky pregnancies due to reproductive organs that are not yet mature enough. Therefore, both adolescents must know and understand about various aspects of reproductive health, including avoiding 
risky pregnancies. According to Nawati \& Nurhayati, pregnancy in adolescents has a high risk, not only damaging the future of the teenager concerned, but also very dangerous for his health. Underage pregnancy carries a high risk of death. Death in pregnant women which can be caused by lack of care and examination during pregnancy. Adolescents who experience pregnancy are prone to pregnancy problems [21]. The purpose of this study was to see an improvement of knowledge and attitudes about risky pregnancies in adolescents at Muhammadiyah 1 Vocational High School in Wonosobo, Indonesia.

\section{RESEARCH METHOD}

This research is a quasi-experimental research or quasi experiment design with a one group pretestposttest design approach that aims to determine the effects arising as a result of certain treatments. This study employed a design using one group from all population. Measurements were made before and after treatment, by pretest and posttest as shown in Figure 1. This design retrieved from two groups as tried variables, by producing two initial observations $(\mathrm{O} 1)$ and final observations $(\mathrm{O} 2)$. X1 is an authorized intervention of a risky pregnancy, $\mathrm{O} 1$ is an initial calculation consisting of $\mathrm{O} 2$ remeasurement of monitoring groups [18].

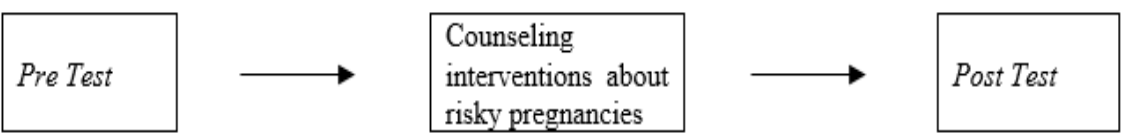

Figure 1. The measurement treatment

The population or research subjects in this study were students of Grade X and XI at Muhammadiyah 1 Vocational High School in Wonosobo amounting to 900 students. Probability sampling technique used is proportionate random sampling. The number of samples taken in this study uses minimum sample based on Slovin formula:

$$
\begin{gathered}
n=\frac{N}{\left(N(d)^{2}+1\right.} \\
n=\frac{900}{\left(900(0.1)^{2}+1\right.} \\
n=\mathbf{9 0} \\
\mathrm{n}=\text { minimum sample size } \\
\mathrm{N}=\text { total population } \\
\mathrm{D}=\text { the desired degree of accuracy of } 0.1 \text { [22] }
\end{gathered}
$$

The minimum number of samples in this study were 90 people. The number of samples in this study was added to $10 \%$ of the total sample, which is 99 people. The number of samples for each class was obtained through the following calculation (Sugiyono):

$$
n D=\frac{\text { Population of Each Class }}{\text { Total Population off All Classes }} \times \text { Sample counts }
$$

$\mathrm{nD}=$ Sample quota for each class

The instrument used in this study was a closed questionnaire consisting of two parts. The first part contains the identities and characteristics of the respondents and the second part is the instrument about knowledge and attitudes about risky pregnancy. Validity and reliability tests were carried out in high schools with the same characteristics as Muhammadiyah Vocational High School in Wonosobo. Table 1 shows the proportional sampling. 
Table 1. Proportional sampling

\begin{tabular}{|c|c|c|c|c|c|}
\hline No & Class & Number of Students & Calculation & Result & Number of Samples \\
\hline 1 & AK X1 & 32 & $\frac{32}{900} \times 99$ & 3.5 & 4 \\
\hline 2 & AK X2 & 32 & $\frac{32}{900} \times 99$ & 3.5 & 4 \\
\hline 3 & AK X3 & 32 & $\frac{32}{900} \times 99$ & 3.5 & 4 \\
\hline 4 & AK X4 & 32 & $\frac{32}{900} \times 99$ & 3.5 & 4 \\
\hline 5 & RPL X1 & 32 & $\frac{3 L}{900} \times 99$ & 3.5 & 4 \\
\hline 6 & RPL X2 & 32 & $\frac{32}{900} \times 99$ & 3.5 & 4 \\
\hline 7 & RPL X3 & 32 & $\frac{32}{900} \times 99$ & 3.5 & 4 \\
\hline 8 & TKJ X1 & 32 & $\frac{32}{900} \times 99$ & 3.5 & 4 \\
\hline 9 & TKJ X2 & 32 & $\frac{32}{900} \times 99$ & 3.5 & 4 \\
\hline 10 & TKJ X3 & 32 & $\frac{32}{900} \times 99$ & 3.5 & 4 \\
\hline 11 & TSM X1 & 32 & $\frac{32}{900} \times 99$ & 3.5 & 4 \\
\hline 12 & TSM X2 & 32 & $\frac{32}{900} \times 99$ & 3.5 & 4 \\
\hline 13 & TSM X3 & 32 & $\frac{32}{900} \times 99$ & 3.5 & 4 \\
\hline 14 & TSM X4 & 32 & $\frac{35}{900} \times 99$ & 3.5 & 4 \\
\hline 15 & AKXI1 & 35 & $\frac{35}{900} \times 99$ & 3.9 & 4 \\
\hline 16 & AK XI2 & 34 & $\frac{34}{900} \times 99$ & 3.7 & 4 \\
\hline 17 & AK XI3 & 35 & $\frac{35}{900} \times 99$ & 3.9 & 4 \\
\hline 18 & RPL XI1 & 35 & $\frac{35}{900} \times 99$ & 3.9 & 4 \\
\hline 19 & RPL XI2 & 35 & $\frac{35}{900} \times 99$ & 3.9 & 4 \\
\hline 20 & RPL XI3 & 34 & $\frac{34}{900} \times 99$ & 3.7 & 4 \\
\hline 21 & TKJ XI1 & 35 & $\frac{35}{900} \times 99$ & 3.9 & 4 \\
\hline 22 & TKJ XI2 & 34 & $\frac{34}{900} \times 99$ & 3.7 & 4 \\
\hline 23 & TKJ XI3 & 35 & $\frac{35}{900} \times 99$ & 3.9 & 4 \\
\hline 24 & TSM XI1 & 35 & $\frac{35}{900} \times 99$ & 3.9 & 4 \\
\hline 25 & TSM XI2 & 35 & $\frac{30}{900} \times 99$ & 3.9 & 4 \\
\hline 26 & TSM XI3 & 35 & $\frac{35}{900} \times 99$ & 3.9 & 4 \\
\hline \multirow[t]{2}{*}{27} & TSM XI4 & 35 & $\frac{35}{900} \times 99$ & 3.9 & 4 \\
\hline & Total & 900 & & & 108 \\
\hline
\end{tabular}

\section{RESULTS AND DISCUSSION}

\subsection{Univariate analysis}

\subsubsection{Characteristics of subjects}

The frequency distribution of the characteristics of respondents in this study was based on age, parental education, parental occupation, parental income and information about teenage pregnancy. This shows that the characteristics of the respondents most of the students aged 17 years were 60 people $(55.6 \%)$. Regarding the education of mothers and fathers, the majority are elementary school graduates with a total of 63 people $(58.3 \%)$. Regarding the occupation of mothers, the majority are housewives with a total of 55 people $(50.9 \%)$. Regarding the occupation of fathers, the majority are farmers amounting to 31 people (28.7\%). Regarding family income, most are more than IDR 1,709,150,- as many as 65 people (60.2\%). The results showed that the majority of students had received information about teenage pregnancy mainly 
obtained from electronic media. Based on the description above, it can be seen the frequency distribution of respondents' characteristics based on the age of the students in Table 2 .

Table 2. Frequency distribution of characteristics of respondents by age

\begin{tabular}{|c|c|c|c|}
\hline \multicolumn{2}{|r|}{ Characteristics } & $\mathrm{F}$ & $\%$ \\
\hline \multirow[t]{5}{*}{ Age } & 15 & 5 & 4.6 \\
\hline & 16 & 21 & 19.4 \\
\hline & 17 & 60 & 55.6 \\
\hline & 18 & 20 & 18.5 \\
\hline & 19 & 2 & 1.9 \\
\hline \multirow[t]{3}{*}{ Mother's Education } & Primary School & 63 & 58.3 \\
\hline & Junior High School & 26 & 24.1 \\
\hline & SeniorHigh School & 19 & 17.6 \\
\hline \multirow[t]{4}{*}{ Father's Education } & Pimary School & 63 & 58.3 \\
\hline & Junior High School & 24 & 22.2 \\
\hline & Senior High School & 20 & 18.5 \\
\hline & College & 1 & 0.9 \\
\hline \multirow[t]{5}{*}{ Mother's Job } & Housewife & 55 & 50.9 \\
\hline & Farmers & 13 & 13.0 \\
\hline & Trader & 21 & 19.4 \\
\hline & Entrepreneur & 5 & 4.6 \\
\hline & Etc & 13 & 12.0 \\
\hline \multirow[t]{6}{*}{ Father's Job } & Labor & 19 & 17.6 \\
\hline & Farmers & 31 & 28.7 \\
\hline & Trader & 18 & 16.7 \\
\hline & Entrepreneur & 24 & 22.2 \\
\hline & Private Sector Worker & 9 & 8.3 \\
\hline & Etc & 7 & 6.5 \\
\hline \multirow[t]{2}{*}{ Parents Income } & $<1,709,150$ (Regional Minimum Wage) & 43 & 39.8 \\
\hline & $>1,709,150$ (Regional Minimum Wage) & 65 & 60.2 \\
\hline \multirow{4}{*}{$\begin{array}{l}\text { Obtain Sources of } \\
\text { Information }\end{array}$} & No Information Obtained & 29 & 26.9 \\
\hline & Print/Non-print Media & 31 & 28.7 \\
\hline & Non-Printed/Electronic & 48 & 44.4 \\
\hline & Total & 108 & 100.0 \\
\hline
\end{tabular}

\subsubsection{Description of the level of knowledge about risky pregnancies}

The description of the research data of respondents' answers shows that the answers are categorized as good, sufficient and less knowledge. Knowledge about risky pregnancies before counseling shows that 77 respondents $(71.3 \%)$ are in the good category and 7 respondents $(6.5 \%)$ are in the less category. Knowledge about risky pregnancy after counseling is mostly in the good category amounting to 89 people (82.4\%) and less categories amounting to 2 people (1.9\%). Based on the description above, it can be seen the frequency distribution of knowledge about risky pregnancies in Table 3.

Table 3. Frequency distribution of knowledge about risks of pregnancy

\begin{tabular}{|c|c|c|c|c|c|c|c|c|}
\hline \multirow{3}{*}{ Knowledge Level } & \multicolumn{6}{|c|}{ Category } & \multirow{2}{*}{\multicolumn{2}{|c|}{ Total }} \\
\hline & \multicolumn{2}{|c|}{ Less } & & \multicolumn{2}{|c|}{ Good } & & \\
\hline & $\mathrm{F}$ & $\%$ & $\mathrm{f}$ & $\%$ & $\mathrm{f}$ & $\%$ & $\mathrm{f}$ & $\%$ \\
\hline Pre-test & 7 & 6.5 & 24 & 22.2 & 77 & 71.3 & 108 & 100 \\
\hline Post-test & 2 & 1.9 & 17 & 15.7 & 89 & 82.4 & 108 & 100 \\
\hline
\end{tabular}

\subsubsection{Description of attitudes about risky pregnancy}

The description of the research data shows that the respondents' answers were categorized as positive and negative attitudes. Attitudes about risky pregnancies prior to counseling were 63 respondents (58.3\%) in the positive category and 45 respondents $(41.7 \%)$ in the negative category. Attitudes about risky pregnancy after counseling were mostly in the positive category amounting to 69 people $(63.9 \%)$ and the negative category amounting to 39 people $(36.1 \%)$. Table 4 shows the distribution of frequency of attitudes about risk pregnancy at Muhammadiyah 1 Vocational High School in Wonosobo. 
Table 4. Distribution of frequency of attitudes about risk pregnancy

\begin{tabular}{ccccccc}
\hline \multirow{2}{*}{ Attitude } & \multicolumn{4}{c}{ Category } & \multicolumn{2}{c}{ Total } \\
& \multicolumn{1}{c}{ Positive } & \multicolumn{2}{c}{ Negative } & \multicolumn{2}{c}{$\%$} \\
Pre-test & $\mathrm{F}$ & $\%$ & $\mathrm{f}$ & $\%$ & $\mathrm{f}$ & $\%$ \\
Post-test & 69 & 58.3 & 45 & 41.7 & 108 & 100 \\
\hline
\end{tabular}

\subsubsection{Prerequisite test}

The results of the normality test were calculated using Kolmogorov Smirnov. The statistical rule for normality test is if $p>0.05$. Table 5 shows that the results of the normality test of the research variables are if knowledge and attitude can be seen that the pretest and posttest variables have a significance value of less than 0.05 ( $\mathrm{p}<0.05)$. The results of the pretest and posttest were distributed abnormally, so the hypothesis test analysis was performed using the Wilcoxon Signed Ranks Test.

Table 5. Normality test result

\begin{tabular}{ccc}
\hline Variable & Statistic & $\mathrm{P}$ \\
\hline Knowledge & & \\
Pre-test & 2.665 & 0.000 \\
Post-test & 2.878 & 0.000 \\
Attitude & & \\
Pre-test & 1.558 & 0.016 \\
Post-test & 2.023 & 0.001 \\
\hline
\end{tabular}

\subsection{Bivariate analysis}

The results of the pretest and posttest knowledge and attitudes about risky pregnancy with a mean rank value at the time of the pretest was 42.08 , while at the posttest was 48.13. The Z_ Wilcoxon Value was 2.989 and the significant value was $0.003(\mathrm{p}<0.05)$. It can be concluded that there is a significant difference between the results of the pretest and posttest on the level of knowledge about risky pregnancy by conducting counseling. These results prove that after intervention, Ho's hypothesis is rejected and Ha is accepted. It means that there is an effect of health education on the level of knowledge about risky pregnancies at Muhammadiyah 1 Vocational High School in Wonosobo in 2018.

The mean rank value at the time of the pretest was 51.76 while at the posttest, it was 39.03.

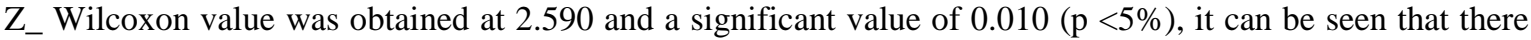
are significant differences in the results of the pretest and posttest on attitudes about risky pregnancy with the existence of reproductive health education. These results as shown in Table 6 prove after the intervention, the hypothesis Ho is rejected and $\mathrm{Ha}$ is accepted. This means that there is an influence of health education on attitudes about risky pregnancies in Wonosobo Vocational School 1 Muhammadiyah.

Table 6. Wilcoxon test

\begin{tabular}{lllll}
\hline Variable & Mean Rank & Sig & Z_Wilcoxon & Information \\
\hline Knowledge & & & & \\
Pre-test & 42.08 & 0.003 & 2.989 & Significant \\
Post-test & 48.13 & & & \\
Attitude & & & & \\
Pre-test & 51.76 & 0.010 & 2.590 & Significant \\
Post-test & 39.03 & & & \\
\hline
\end{tabular}

The results of the study before counseling showed that respondents who had knowledge in the good category were 77 people $(71.3 \%)$, and after counseling, the results showed that respondents who had knowledge in the good category were 89 people $(82.45 \%)$. These results have little difference and prove that most students already have good knowledge of risky pregnancies. After counseling, 2 students at Muhammadiyah 1 Vocational High School in Wonosobo (1.9\%) had a less of knowledge about risky pregnancies. Less of knowledge is influenced by several factors including education, age, environment, socio-culture and this shows that counseling given to students has been done but there are still students who do not have good knowledge about risky pregnancy. This can be caused by the fact that respondents have not been able to understand well the material provided when counseling about these risky pregnancies, so that 
the knowledge they can receive is limites. Research conducted by Dewi showed that the knowledge of adolescent girls about early pregnancy was mostly in the good category of 280 people (98.6\%) [19].

Knowledge is one of the predisposing factors for a risky pregnancy. Less of knowledge or limited knowledge about high risk pregnancies and the dangers that will be experienced will also increase the incidence of high risk pregnancies. Behavioral and socioeconomic also influence the risk in pregnancy. Knowledge and practice at the adolescent stage will be the basis of healthy behavior at a later stage in life. Thus, investing in adolescent reproductive health programs during life will be beneficial [23]. Efforts that can be done by adolescents in increasing their knowledge are through mass media information and health services in schools and health institutions. Adolescents can dig more information about risky pregnancies so they can avoid unwanted pregnancies. Students who have good knowledge can take part in IHC-CTR activities and become peer counselors so that they can provide information to other students who do not know about risky pregnancies.

Before counseling, the results of the study showed that respondents who had positive attitudes towards risky pregnancies were 63 people $(58.3 \%)$ and after counseling, the results showed that respondents who had positive attitudes towards risky pregnancies were 69 people $(63.9 \%)$. These results prove that most students have good attitude about risky pregnancy. The positive attitude referred to in this study is the tendency to avoid or prevent risky pregnancies.

The attitude of students about risky pregnancies at Muhammadiyah 1 Vocational High School in Wonosobo is known to number 45 people (41.7\%) people are hegative (tendency to approach risky pregnancy behavior). Student attitudes can be influenced by several factors including personal experience, the influence of others, emotional factors, culture, mass media, education and religion [24]. Efforts that can be done by adolescents in enhancing negative attitudes about risky pregnancies is to be more careful about relationships that tend to be related to the abuse of sexual function that can cause pregnancy at young age.

Research conducted by Dewi shows that adolescents have good knowledge but do not consistently show good attitudes towards pregnancy in their teens. Adolescents have negative attitudes that lead to high risks such as hugging during courtship and kissing forehead [19]. Attitude is a reaction or response that is still closed from someone which is a combination of cognitive and affective towards an object or stimulus [24]. Adolescent attitudes towards pregnancy at an early age are an important part of being able to understand the phenomenon of an increasing number of cases of early pregnancy which are very risky. Attitude is a willingness or readiness to behave [18]. Social attitudes and norms are an important part of adolescent life in making decisions to behave risky.

Counseling about risky pregnancies conducted at Muhammadiyah 1 Vocational High School in Wonosobo shows that from the measurement of pretest and posttest, it can be seen that knowledge and attitudes are increased. The results of the knowledge variable analysis showed a significant value of 0.003 ( $\mathrm{p}<0.05)$. These results prove after the intervention, there is an influence of counseling on the level of knowledge about risky pregnancies at Muhammadiyah 1 Vocational High School in Wonosobo. The results of the attitude variable analysis showed a significant value of $0.010(\mathrm{p}<0.05)$. These results prove after the intervention, there is the effect of counseling on attitudes about risky pregnancies in Muhammadiyah 1 Vocational High School in Wonosobo.

At the time of the research, the conditions and conditions were very supportive and the process also received positive responses from students due to several influencing factors. These factors are the absence of students doing research at Muhammadiyah 1 Vocational High School in Wonosobo, there is no counseling from the Wonosobo Health Office on reproductive health (risky pregnancy), no biology subjects, and the less of counseling guidance on reproductive health so that students are very enthusiastic to follow the stages of research and are supported by way of delivering interesting counseling such as using powerpoints, material that is packaged simply, delivering clear information will be easily understood and understood by respondents, and at the end of the counseling there is a question and answer session so that it will increase students' knowledge about pregnancy risk properly and correctly.

The results of several studies of prior knowledge indicate that an increase in adolescent knowledge about reproductive health after health education was conducted [5]. This shows that there is an influence of health education on adolescent knowledge [25]. Wilcoxon statistical test results obtained $\mathrm{p}$ value $<0.0001$ $<\alpha=0.05$ means Ho was rejected and it was concluded that there was an influence of counseling activities in AHCS on adolescent knowledge about premarital sex. Before conducting counseling in AHCS activities, the majority of respondents had good knowledge of $39.3 \%$ and after counseling about premarital sex of respondents who were well knowledgeed were $80.4 \%$. Based on the Wilcoxon test results, with $\mathrm{P}$ value $=0.000$, because $\mathrm{P}$ value $=0.000<\alpha(0.05)$ then Ho is rejected and Ha is accepted, this shows that there is a significant effect of counseling on adolescent knowledge in Binsus 9 Manado High School [26]. Distribution of respondents based on the level of knowledge before counseling about the dangers of free sex with a good frequency of knowledge level of 2 people (5.4\%) and after counseling 
about the dangers of free sex, those with a frequency of good knowledge level amounted to 34 people (91.9\%).Setyorini's research shows the same results, namely the influence of health education about the dangers of premarital sex on knowledge and attitudes, the level of knowledge of the dangers of premarital sex. 63 people (95\%) [27]. The results of several previous studies indicate that there are differences in knowledge before and after counseling.

Supporting results from research on attitudes conducted by Udu show that there is an influence of counseling interventions on adolescent attitudes about reproductive health [28]. Before conducting counseling activities that are part of AHCS, respondents behaved well with $69.6 \%$. Whereas after the outreach activities carried out in AHCS, respondents with good attitude became $91.1 \%$ and research conducted by Setyorini showed that there was a change in attitude before counseling and after counseling [25, 27]. Information about the level of adolescent knowledge of early pregnancy is an important part of being able to understand the phenomenon of an increasing number of cases of risky pregnancies. This information is also a feedback on the reproductive health program held in schools [19]. Knowledge is one of the predisposing factors for a risky pregnancy. Less of knowledge or limited knowledge about high risk pregnancies and the dangers that will be experienced, will also increase the incidence of high risk pregnancy, behavior and socioeconomic also affect the risks in pregnancy [23].

Adolescent attitudes about pregnancy are closely related to peer's relationships. Therefore, students need a peer counselor at school to help improve good adolescent attitudes, especially in preventing risky pregnancies. Peer counseling is an event to complain to each other, pour out their hearts, strengthen each other and motivate each other among fellow students. Counseling basic skills training conducted for IHC-CTR administrators in high school based on modules through reading activities, discussion activities, and practicing activities so that YIAC administrators can have knowledge and insight about the implementation of counseling as an effort to solve problems and can help the implementation of teacher tasks counseling guidancein peer relationship services [29].

Counseling is very important in providing information to the public, especially adolescents who are still at risk of unwanted pregnancy. Notoatmodjo argues that health education is an effort for the public to behave or adopt health behaviors by means of appeal, solicitation, providing information, providing awareness and so on [18]. Counseling can have a positive impact in order to increase knowledge, awareness, willingness and ability of people to live healthy and actively participate in health efforts. Knowledge about risky pregnancy can be influenced by information and knowledge factors obtained from print media, mass media and counseling that have been given. The condition of a supportive school environment for the health of school members such as adequate health facilities and infrastructure, having a school health unit that is actively used, will certainly have an impact on good health behavior for school residents. Pregnancy in adolescence has a high medical risk because in adolescence the reproductive organs are not mature enough to perform its function. Active premarital sex in adolescents is at risk for teenage pregnancy and transmission of sexually transmitted diseases. Unplanned pregnancies for adolescent girls can lead to teenage abortion and marriage. Both will have an impact on the future of adolescents and increase risky pregnancies in adolescents [30].

\section{CONCLUSION}

There is an influence of health education on the improvement of knowledge about risky pregnancy in Muhammadiyah 1 Vocational High School in Wonosobo. There is an effect of reproductive health counseling on the improvement of attitudes about risky pregnancy at Muhammadiyah 1 Vocational High School in Wonosobo. Counseling can form peer counselors so students have good knowledge and attitudes related to risky pregnancies, as well as increase student motivation to choose good and positive relationships. Students who have never received information related to pregnancy are at risk so students are expected to dig deeper information by attending school health counseling, looking for information in the mass media, books, or asking people who are experts in their fields.

\section{REFERENCES}

[1] S. Wulandari, "Risk of Sexual Behavior Towards Unwanred Pregnancy in Adolescents Of SMKN Tandum of Rokan Hulu Regency," J. Matern. neonatal, vol. 2, no. 2, pp. 74-84, 2016.

[2] M. Azinar, "Premarital Risk for Unwanted Pregnancy," J. Kesehat. Society, vol. 8, no. 2, pp. 153-160, 2013.

[3] WHO, Preventing Early Pregnancy and Poor Reproductive Results, 2017. [Online]. Available: https://www.who.int/gho/maternal health / en / index.html

[4] P.R. Regmi, E. van Teijlingen, P. Simkhada, and Acharya, "Sexual Barriers to Youth Health Services in Nepal," J. Healing. popul Nutr., vol. 28, no. 6, pp. 619-627, 2010. 
[5] P. DN, "Effects of Peer Education Group Health on Adolescent Girls' Knowledge and Attitudes About Reproductive Health," J. Kep., vol. 2, no. 3, 2014.

[6] Azinar, Muhammad, "Premarital Sexual Behavior Risk of Unwanted Pregnancy," KEMAS: Journal of Public Health, vol. 8, no. 2, pp. 153-60, 2013.

[7] Abrori, Deviated from the Path of Abortion. Gigih Independent Library, 2014.

[8] Widyoningsih, et al., "Health Problems Faced by Families in Caring for Adolescents With Unwanted Pregnancy (KTD)," Al-Irsyad Health Journal (JKA), vol. 2, no. 2, pp. 72-83, 2014.

[9] Effendi, Nurmaya, and Harti Widiastuti, "Journal of Health," Journal of Health, vol. 7, no. 2, pp. 353-60, 2014.

[10] Arub, Lathifah, "The Relationship between Parenting Parents and Adolescent Sexual Behavior in SMK Negeri 1 Sewon Bantul," Aisyiyah University Yogyakarta, 2017. [Online]. Available: http://digilib.unisayogya.ac.id/2746

[11] N.K. Febyanti and D. Susilawati, "Relationship of Knowledge of Pregnant Women about Antenatal Care for Pregnancy Visit Behavior," J. Nursing Soedirman (The Soedirman J. Nursing), vol. 7, no. 3, pp. 148-157, 2012.

[12] V.J. Lumempouw, R.M. Kundre, and Y. Bataha, "Relationship between Socio-Economic Factors of Pregnant Women with Regular Antenatal Care (ANC) Examination at Ranotana Weru Health Center, Wanea District, Manado City," e-Journal of Nursing (e-Kp), vol. 4, no. 2, pp. 1-7, 2016.

[13] A. Teguh and T. Istiarti, "Relationship of Knowledge, Attitudes Towards Reproductive Health with Pre-marital Sex Practices in Midwifery Students at the Semarang Polytechnic Health Department," J. Kesehat. Society, vol. 2, no. 2 , pp. 1-10, 2013.

[14] Senja, Andika Oktavian, Yuni Puji Widiastuti, et al., "The Level of Knowledge Adolescent About Reproductive Health," Journal of Nursing, vol 12, no. 1, pp. 85-92, 2020.

[15] Marmi, Reproductive Health. Student Library, 2013.

[16] IDAI, "Adolescent Reproductive Health in Social Aspects," 2017. [Online]. Available: http://www.idai.or.id/artikel/seputar-kempuan-anak/k health-reproduction-remaja-dalam-aspek-social

[17] B. T. Husodo and L. Widagdo, "Reproductive Health Education in Semarang City," Makara, Kesehat., vol. 12, no. 2, pp. 59-62, 2008.

[18] S. Notoatmodjo, "Behavioral Health Sciences," 2010.

[19] D.A.K. Dewi and D.S. Lubis, "The level of knowledge and attitudes of young women around early pregnancy in the city of Denpasar," Indones. J. Halth General, vol. 1, no. 1, pp. 63-68, 2012.

[20] D. Sari, "In Pipkesmas Ciputat Kota Tangerang Selatan In 2014," ARKESMAS, vol. 1, no. 1, pp. 4-17, 2016.

[21] Nawati and Nurhayati, "The Impact of Unwanted Pregnancy on Pregnancy and Infant Care," Journal of Maternal and Child Health, vol. 9, no. 1, pp. 22-25, 2018.

[22] Nursalam, "Concepts and Application of Nursing Research Methodologies," 2008

[23] Septiana and E. Tjahjani, "Risk of Incident Pregnancy Based on Knowledge Level of Trimester III Pregnant Women," J. Akad. Midwifery Griya Husada, vol. 2, no. 1, pp. 38-43, 2015.

[24] AS, "Human Attitude Theory and Its Measurement," 2011.

[25] N. Rahayu, Y. Yusad, and R.M. Lubis, "The Effect Of Extension Of Activities In The Health Services of Adolescents (Pkpr) in Knowledge And Adolescent Attitudes About Pranicah Sex In Sman 1 Lubukdalam Siak Sri Indrapura District Of Year, Gizi," J. Nutrition Healthy. Reproduction and Epidemiol, vol. 2, no. 5, pp. 1-8, 2013.

[26] W. Bachruddin, F. Kalalo, and R. Kundre, "The Effects of Counseling on the Dangers of Free Sex on Youth Knowledge About Free Sex in Binsus 9 Manado Public High School," e-Journal of Nursing (e-Kp), vol. 5, no. 1, pp. 1-7, 2017.

[27] Zulfikar, F.J. Kunoli, M. Jufri, and Rafiudin, "The Effects of Health Education About Premarital Sex on Knowledge Students in Bolano Lambunu 1 High School," J. Collaborative Science, vol. 1, no. 1, pp. 551-558, 2018.

[28] W.S.A. Udu and P.Y.W. Wiradirani, "Effects of intervention counseling on adolescent knowledge and attitudes about reproductive health," Medula, vol. 1, no. 2, pp. 71-75, 2014.

[29] A.H. Rahmawati, "Counseling Increased Skills Of Counselor colleagues in MAN Yogyakarta 1," E-Journal supervised and Counseling, vol. 4, no. 5, pp. 1-12, 2016.

[30] K. RI, Infodatin: Adolescent Reproductive Health Situation. Indonesian TRC, Ed. Jakarta, 2013.

Int. J. Eval. \& Res. Educ. Vol. 9, No. 2, June 2020: 326 - 334 